\title{
Incidence of gestational trophoblastic disease in Tokat province, Turkey
}

\author{
Bülent Çakmak ${ }^{1}$, Muhammet Toprak ${ }^{1}$, Mehmet Can Nacar', Reşid Doğan Köseoğlu², Nihan Güneri ${ }^{3}$ \\ 'Department of Obstetrics and Gynecology, Gaziosmanpaşa University Faculty of Medicine, Tokat, Turkey \\ ${ }^{2}$ Department of Pathology, Gaziosmanpaşa University Faculty of Medicine, Tokat, Turkey \\ ${ }^{3}$ Department of Obstetrics and Gynecology, Tokat Government Hospital, Tokat, Turkey
}

\section{Abstract}

Objective: This study investigated the incidence of gestational trophoblastic disease (GTD) in Tokat province, Turkey.

Material and Methods: The medical records of patients who had been diagnosed and treated at one university hospital, six government hospitals, and one specialist hospital in Tokat province between January 2005 and December 2012 were evaluated retrospectively.

Results: During the study period, there were 59,754 births and GTD was diagnosed in 73 cases. The calculated GTD incidence was $1.22 / 1000$. The mean age of the patients diagnosed with GTD was $28.6 \pm 7.3$ (range 17-51) years. In GTD, complete moles occurred in $26 \%$, partial moles in $74 \%$, and no invasive moles, choriocarcinomas, or placental site trophoblastic tumours were found. Only two patients received chemotherapy (methotrexate). There was no mortality associated with the disease during follow-up.

Conclusion: The incidence of GTD in Tokat province was 1.2 per 1000 births. Early diagnosis, treatment, and follow-up play a critical role in preventing the morbidity and mortality associated with disease. The incidence of GTD, which has a high recovery rate with adequate treatment and follow-up, can be determined from regional and community-based research. (J Turk Ger Gynecol Assoc 2014; 15: 22-4)

Key words: Gestational trophoblastic disease, molar pregnancy, incidence

Received: 11 October, 2013

Accepted: 09 November, 2013

\section{Introduction}

Gestational trophoblastic disease (GTD) is classified histopathologically as complete or partial mole, invasive mole, placental site trophoblastic tumour, and gestational choriocarcinoma (1). Menarche age, parity, first pregnancy age, mole pregnancy history, time interval between previous pregnancies, genetic factors, malnutrition, viral infections, and socioeconomic level all predispose to GTD (2). The aetiology is not clear, but the disease is characterised by abnormal gametogenesis, fertilisation, and malignant transformation of trophoblastic tissue.

The incidence of GTD differs across geographic regions. The reported GTD incidence was 0.3-16 per 1000 pregnancies in Turkey, 0.6-1.2 in Europe and North America, 0.2-4.6 in Latin America, and 3.2-5.8 in Middle East countries $(3,4)$. This study determined the incidence of GTD in Tokat province, Turkey.

\section{Material and Methods}

This study was performed between January 2005 and December 2012 and patients were collected from one university hospital, six government hospitals, and one private hospital in Tokat. The study protocol was approved by the Medical
Ethics Committee and informed consent was taken. The patients diagnosed with GTD were confirmed histopathologically. Epidemiological data, laboratory and pathology results, and follow-up examination findings were obtained from the patients' records. Some information was obtained by telephoning patients when it was missing from the records. GTD was classified as complete and partial mole, invasive mole, placental site trophoblastic tumour, and gestational choriocarcinoma. Patients diagnosed with GTD were evaluated according to their age, pregnancy, birth, abortion number, and histopathology. All data were analysed using "PASW Statistics version 18.0" (PASW, Chicago, IL, USA). Data were given as mean $\pm \mathrm{SD}$ (standard deviation) and $\mathrm{n}(\%)$.

\section{Results}

Between January 2005 and December 2012, there were 59,754 births in Tokat province. During this period, 73 cases were diagnosed as GTD histopathologically. The calculated GTD incidence was 1.22 per 1000 births. The mean age of the diagnosed patients was 28.6 \pm 7.3 (range 17-51) years. Many patients were aged 20-29 years (Figure 1). The mean numbers of pregnancies, births, and abortions were $3.5 \pm 2.9$ (range 1-15), 1.3 \pm 1.4 (range 0-5), and 1.1 \pm 2.3 (range 0-13), 
respectively. There was no history of molar pregnancy in any case. Comparing blood types, $45.9 \%$ were type A, $21.3 \%$ were type $\mathrm{B}, 31.1 \%$ were type $\mathrm{O}$, and $1.6 \%$ were type $\mathrm{AB}$. Vacuum curettage was performed in all patients for diagnosis and treatment. Histopathologically, 26\% were complete moles, 74\% were partial moles, and there were no invasive moles, choriocarcinomas, or placental site trophoblastic tumours (Figure 2). Two patients were treated for non-metastatic disease with single-agent chemotherapy (methotrexate) (Emthexate; Med Ilac, İstanbul, Turkey) and were cured. No hysterectomy was performed in any patient and there was no disease-dependent mortality during the follow-up period.

\section{Discussion}

Gestational trophoblastic disease, which arises from the abnormal proliferation of trophoblasts, is seen in $0.6-11.5$ per 1000 pregnancies; however, this ratio differs among communities $(2,5,6)$. The suggested GTD incidence is $0.3-16$ per 1000 gestations (4). The incidence of GTD also differs among regions in Turkey. The incidence is 12.1 per 1000 births in Şanllurfa, 8.1 in Van, 1.78 in Ankara, 3.35 in Konya and 5.9 in Istanbul (7-11). The reason for the increased GTD incidence in these cities might be the fact that these studies were performed in referral centres (10). Özalp et al. (12) conducted a society-based study, and found an incidence of 0.8 per 1000 live births and 0.6 per 1000 preg-

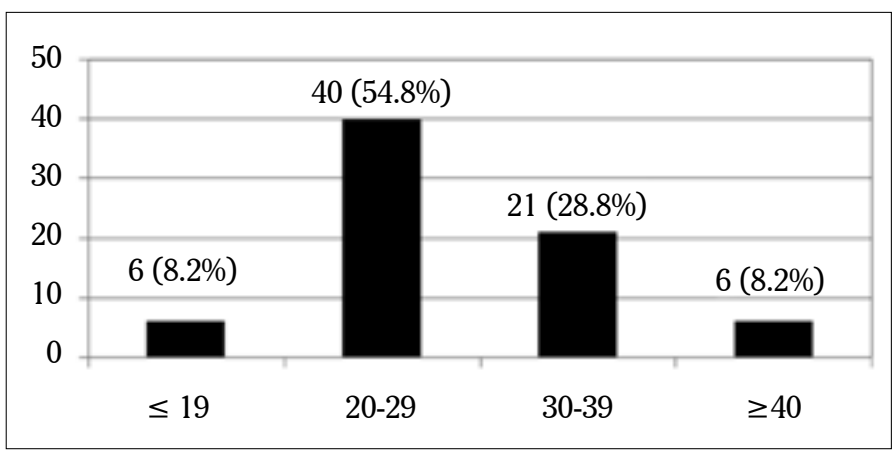

Figure 1. The distribution of patients according to age range

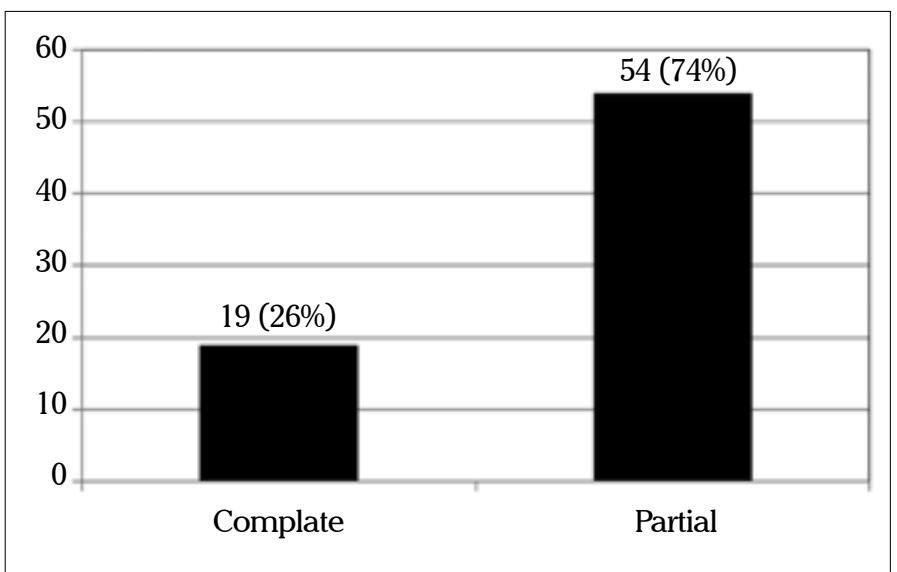

Figure 2. The distribution of patients according to histopathological diagnosis nancies. Our study is the first conducted in Tokat and the GTD incidence was 1.22 per 1000 live births. It is apparent that the GTD incidence is lower when studies are based on large communities.

Çetin et al. (13) found that the incidence of GTD was 6.60 per 1000 births in Sivas province, so the incidence differs among regions. This rate is approximately six-fold higher than in our study. In comparison, Malatyalığlu et al. (14) reported a GTD incidence of 0.3 per 1000 pregnancies in Samsun. Unlike other studies, however, they calculated the incidence using the number of pregnancies, not births. Given the differences among regions, the incidence can differ between two cities, possibly because the calculation can be based on the number of pregnancies or births.

In our study, GTD was most common in the third decade of life and the mean patient age was $28.6 \pm 7.3$ (range 17-51) years. In the literature, the disease is usually seen during the early and late fertility periods, i.e. younger than 20 and older than 35 years $(15,16)$. GTD in Turkey usually occurs at ages from 19-35 years $(11,17)$. We found that blood type A $(45.9 \%)$ was the most frequent, and this is the most common maternal blood type $\mathrm{A}$ in the literature $(8,11)$.

Vacuum curettage, hysterectomy, and chemotherapy are usually used to treat GTD. In our study, vacuum curettage was performed in all patients, while no hysterectomies were done. In the literature, hysterectomy is usually used to treat old grand multiparity patients because malignant degeneration increases with age and the risk decreases from $20 \%$ to $3-10 \%$ with hysterectomy $(18,19)$.

Chemotherapy is given if the $\beta$-hCG level plateaus or increases or stays high for more than 6 months, choriocarcinoma is diagnosed histologically, or metastatic disease is present (20). Chemotherapy is based on the anatomical staging of the International Federation of Gynecology and Obstetrics (FIGO) and a prognostic scoring system devised by the World Health Organisation and modified by FIGO. Methotrexate or actinomycin is usually used as a single agent, while methotrexate, actinomycin$\mathrm{D}$, and cyclophosphamide (MAC) or etoposide, methotrexate, actinomycin-D, cyclophosphamide, and vincristine (EMA-CO) combinations are used as multiple treatment modalities (21). Cures are obtained in $100 \%$ of the low-risk group and $80-90 \%$ of the high-risk group $(20,22,23)$. In our study, only two patients were treated with methotrexate because of persistent $\beta$-hCG. No chemotherapy-dependent morbidity occurred.

In conclusion, the incidence of GTD in Tokat province was 1.22 per 1000 births. Early diagnosis, treatment, and follow-up are important to prevent morbidity and mortality. We believe that sufficient treatment and follow-up will facilitate the cure of GTD and the incidence can be calculated more accurately by performing broad community-based studies.

Ethics Committee Approval: Ethics committee approval was received for this study from the Medical Ethics Committee.

Informed Consent: Written informed consent was obtained from patient who participated in this study.

Peer-review: Externally peer-reviewed. 
Author contributions: Concept - B.Ç., M.T.; Design - B.Ç., M.T., D.R.K.; Supervision - B.Ç.; Resource - B.Ç., M.T., N.G.; Materials B.C.,M.C.N.; Data Collection\&/or Processing - B.Ç., M.T., N.G., D.R.K.; Analysis\&/or Interpretation - B.C., M.T.; Literature Search B.Ç., M.C.N.; Writing - B.Ç., M.C.N.; Critical Reviews - B.C.., D.R.K.

Conflict of Interest: No conflict of interest was declared by the authors.

Financial Disclosure: The authors declared that this study has received no financial support.

\section{References}

1. Berkowitz RS, Goldstein DP. Gestational Trophoblastic Disease. In: Berek JS, Adashi EY, Hillard PA, editors. Novak's Gynecology. Philadelphia, USA: Mass Publishing CO. 1996.p.1261.

2. Ghaemmaghami F, Ashraf-Ganjooie T. Gestational trophoblastic neoplasia. Asia-Pacific J Clin Oncol 2006; 2: 9-21. [CrossRef]

3. Ozalp SS, Yalcın OT, Tanır HM. Hidatiform mole in Turkey from 1932 to 2000. Int J Gynecol Obstet 2001; 73: 257-8. [CrossRef]

4. Altieri A, Franceschi S, Ferlay J, Smith J, La Vecchia C. Epidemiology and etiology of gestational trophoblastic diseases. Lancet Oncol 2003; 4: 670-8. [CrossRef]

5. Hayashi K, Bracken MB, Freeman DH Jr, Hellenbrand K. Hydatidiform mole in United States (1970-1977): a statistical and theoretical analysis. Am J Epidemiol 1982; 115: 67-77.

6. Palmer JR. Advences in the epidemiology of gestational trophoblastic disease. J Reprod Med 1994; 39: 155-60.

7. Harma M, Harma M, Yurtseven S, Gungen N. Gestational trophoblastic disease in Sanliurfa, southeast Anatolia, Turkey. Eur J Gyneacol Oncol 2005; 26: 306-8.

8. Kurdoğlu M, Kurdoğlu Z, Küçükaydın Z, Şahin GHG, Kamacı M. Gestational trophoblastic diseases: Fourteen year experience of our clinic. J Turk Soc Obstet Gynecol 2011; 8: 134-9. [CrossRef]

9. Oguz S, Karakoca GA, Aydoğdu T, Gökmen O. Clinical analysis of 165 gestational trophoblastic disease cases. T Klin Jinekol Obst 2002; 12: 87-94.

10. Gezginç K, Görkemli H, Çelik Ç, Acar A, Çolakoğlu C, Akyürek C. Kliniğimizdeki gestasyonel trofoblastik hastalıklı vakaların analizi. Türk Jinekolojik Onkoloji Dergisi 2004; 7: 70-4.
11. Yumru AE, Dinçgez B, Ondeş B, Bozyiğit A. Epidemiologic characteristics and management of subjects who were diagnosed with trophoblastic disease. Erciyes Med J 2012; 34: 106-10. [CrossRef]

12. Ozalp S, Metintaş S, Arslantaş D, Işikli B, Kalyoncu C. Frequency of hydatidiform mole in the rural part of Eskişehir, Turkey. Eur $\mathrm{J}$ Gynaecol Oncol 2003; 24: 315-6.

13. Çetin M, Balta Ö, Duran B, Güvenal T, Yanar O. A retrospective study of molar pregnancy cases submitted to our clinic. CÜ Tip Fakültesi Dergisi 2004; 26: 18-22.

14. Malatyalığlu E. Clinical evaluation of 19 gestational trophoblastic neoplasms. Ondokuz Mayıs Üni Tıp Fak Derg 1990; 7: 331-43.

15. Matsui H, litsuka Y, Suzuka K, Seki K, Sekiya S. Subsequent pregnancy outcome in patients with spontaneous resolution of HCG after evacuation of hydatidiform mole: comparison between complete and partial mole. Hum Reprod 2001; 16: 1274-7. [CrossRef]

16. Lurain JR. Pharmacotheraphy of gestational trophoblastic disease. Expert Opin Pharmacother 2003; 4: 2005-17. [CrossRef]

17. Kars B, Taşlıgedik G, Karşıdağ YK, Büyükbayrak EE, Pirimoğlu ZM, Sargin M, et al. 2005-2009 ylları arasında molar gebelik nedeniyle tedavi olan hastaların takibi ve değerlendirilmesi. Türk Jinekolojik Onkoloji Dergisi 2011; 1: 26-32.

18. Jones WB, Lewis JL. Integration of surgery and other tecniques in the management of trophoblastic disease. Obstet and Gynecol Clin North Am 1988; 15: 565-76.

19. Bahar AM, El-Ashnehi MS, Senthilselvan A. Hydatidiform mole in elderly: Hysterectomy or evacuation. Int J Obstet Gynecol 1989; 29: 233-8. [CrossRef]

20. Lurain JR. Gestational trophoblastic disease II: Classification and management of gestational trophoblastic neoplasia. Am J Obstet Gynecol 2010; 204: 11-8. [CrossRef]

21. Alazzam M, Tidy J, Osborne R, Coleman R, Hancock BW, Lawrie TA. Chemotherapy for resistant or recurrent gestational trophoblastic neoplasia. Cochrane Database Syst Rev 2012; 12: CD008891.

22. Newlands ES. The management of recurrent and drug resistant gestational trophoblastic neoplasia (GTN). Best Pract Res Clin Obstet Gynecol 2003; 17: 905-23. [CrossRef]

23. Ghaemmaghami F, Behtash N, Soleimani KH, Hanjani P. Management of patients with metastatic gestational trophoblastic tumor. Gynecol Oncol 2004; 94: 187-90. [CrossRef] 